\title{
ENFLURANE (ETHRANE*) AND ISOFLURANE (FORANE*): \\ A COMPARISON WITH NINE GENERAL ANAESTHETICS DURING STRESS OF HYPOXIA (SPONTANEOUS BREATHING)
}

\author{
Allen B. Dobkin, B.A., M.D., F.R.C.P.(C), Peter H. Byles, M.B., B.S., \\ and Ashley A. Levy, PH.D.
}

EXCEPT WITH DIETHYL ETHER, no appreciable metabolic disturbances develop during general anaesthesia even with mild ${ }^{1}$ to severe ${ }^{2}$ hypoxia ( 15 per cent and 10 per cent oxygen) for 90 minutes, provided that normal pulmonary ventilation is maintained.

In a comparative evaluation of enflurane and isoflurane, we did not observe a deleterious circulatory response in dogs subjected to 30 minutes of apnoea induced by anaesthesia plus muscle relaxants, with oxygen insufflation ("apnoeic oxygenation"). All of the animals survived the test. ${ }^{3}$

Thereupon we attempted a crossover study to determine the physiological and biochemical effects of general anaesthesia in dogs with acute hypoxia ( 8 per cent to 10 per cent inspired oxygen concentration) for 90 minutes with spontaneous breathing.

The original design for the investigation was abandoned because most of the animals did not survive. Review of the data suggested several factors contributory to the high mortality. The depth and duration of anaesthesia was too great to permit adequate pulmonary ventilation and optimal myocardial contractility. Blood volume was significantly reduced by sampling for laboratory tests. Liver glycogen stores and blood sugar were depleted and serum potassium and plasma insulin were reduced. The degree of hypoxia was evidently more than a dog's heart could tolerate during deep anaesthesia with spontaneous breathing., ${ }^{4,5}$

This report describes a modified experimental approach and compares the response to enflurane and isoflurane with the responses to seven other inhalation anaesthetics and two parenteral anaesthetics.

\section{Materials and Methods}

Employing a crossover design, anaesthetics were administered at least 6 times with each of 11 agents, using 22 large (21 to $33 \mathrm{~kg}$ ) trained male mongrel dogs for the 72 individual tests. Each animal received at least three different anaesthetics at three-week intervals, as follows:

- Trademark of Ohio Medical Products, Division of Airco, Ine.

From the Department of Anesthesiology, State University of New York, Upstate Medical Center, Syracuse, New York 13210, U.S.A.

This project was supported by grants-in-aid from Ayerst Laboratories, Airco, Inc., U.S.P.H.S. Grant 05402-04,5 and by the Division of Research Facilities and Resources of NIH (Grant FR00353). 
TABLE I

Anaesthetic Agents and Vapourisers Used to Maintain Anaesthesia FOR 90 MINUTES FOLloWING INDUCTION WiTH 20 M.P.K. ThIOPENTONE I.v. (Spontaneous Breathing)

\begin{tabular}{|c|c|c|}
\hline Agent & Peak Vapour and Gas Concentration & Vapouriser \\
\hline $\begin{array}{l}{ }^{*} \text { Methoxyflurane } \\
\text { Chloroform } \\
\text { Trichlorethylene } \\
{ }^{*} \text { Halothane } \\
\text { Halothane Ether Azeotrope } \\
\text { *Isoflurane } \\
\text { *Enflurane } \\
\text { Diethyl Ether } \\
\text { *Fluroxene } \\
\text { Innovar } \\
\text { Thiopentone } \quad(1 \mathrm{ml} \\
\end{array}$ & 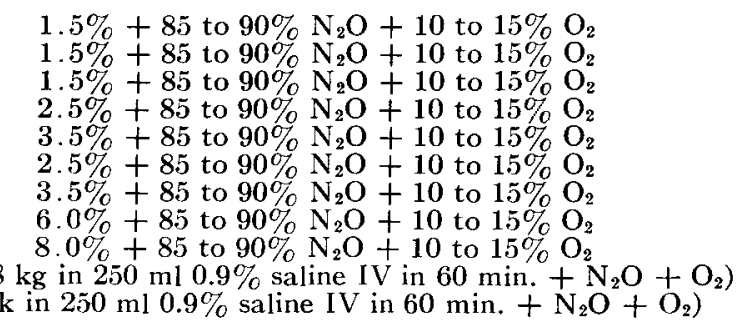 & $\begin{array}{l}\text { Pentec } \\
\text { Chlorotec } \\
\text { Tritec } \\
\text { Fluotec } \\
\text { Fluotec } \\
\text { Fluotec } \\
\text { Fluotec } \\
\text { EMO } \\
\text { Vernitrol }\end{array}$ \\
\hline
\end{tabular}

Each anaesthetic agent was given to at least 6 dogs in a non-rebreathing system with a total gas flow of approximately 1.5 litres oxygen and 8.5 litres nitrous oxide via a 5 -litre reservoir bag and a vapouriser.

*Vapour concentrations were checked with a Mayo Analyser.

An unpremedicated dog, fasted overnight, was weighed; a cannula was inserted in a foreleg vein and blood was drawn for laboratory tests (control); then, an infusion of 0.9 per cent saline was started. Anaesthesia was induced with $20 \mathrm{mg} / \mathrm{kg}$ thiopentone given intravenously in a 2 per cent solution. A cuffed tracheal tube was passed and connected to an anaesthetic machine delivering 100 per cent oxygen through a $\mathrm{Y}$-connector with one-way valves. A Wright respirometer was attached to the expiratory limb of the non-rebreathing system, while a 5litre reservoir bag was fitted on the inspiratory limb.

ECG lead 2, a rectal temperature probe, a urinary catheter attached to a calibrated trap and an arterial plastic cannula for sampling and for recording mean arterial blood pressure were inserted. Anaesthesia was administered with an agent as listed in Table I. The concentration of the anaesthetic vapour was gradually increased over the first 30 minutes, and then maintained at the peak concentration for 60 minutes. Inspired nitrous oxide:oxygen was gradually adjusted from $85: 15$ to $90: 10$ per cent during the first 30 minutes of the test, then was maintained at 90:10 per cent for the remaining 60 minutes. At the end of the test period, venous and arterial blood samples were drawn again for laboratory tests. Then the nitrous oxide flowmeter and the vapourizer were closed and 100 per cent oxygen was given until the dog awakened. After this, he was extubated and observed until ambulation was steady. At 10-minute intervals during each anaesthetic period a reading and notation were made of the mean arterial blood pressure from a damped aneroid manometer attached to the femoral artery cannula; heart rate was read from the electrocardiogram; minute ventilation and rate of respiration were read from the respirometer and urine output and saline input were read from the urine trap and solution bottle, respectively. During anaesthesia and recovery, notes were also kept of such events as cardiac arrhythmias, salivation, twitching and cyanosis. 


\section{Laboratory Procedures}

Arterial blood samples were analysed for blood gases and related parameters with an Instrumentation Laboratory, Inc., Model $113 \mathrm{pH} /$ blood gas analyzer. Oxygen saturation was determined with a reflection oximeter (American Optical Company, Model 10,800). Lactate and pyruvate were measured in whole arterial blood by the method of Gelder and Neville. ${ }^{6}$ Other blood analyses listed in the tables were carried out by standard laboratory procedures as reported previously. ${ }^{1-3}$

\section{Results}

Mean Arterial Blood Pressure (MABP), Heart Rate, Electrocardiogram (ECG) and Urine Output (Table II)

$M A B P$ fell gradually with methoxyflurane, halothane, halothane-ether azeotrope, isoflurane, enflurane and Innovar. It rose moderately with fluroxene and thiopentone and was virtually unchanged with chloroform, trichlorethylene and diethyl ether.

TABLE II

Summary of Changes in Mean Arterial Blood Pressure (mmHg), Heart Rate (Per Minute), Urine Output (ML) and 0.9 Per Cent Saline (ML) Administered During

Aoministration of General Anaesthetics With a Hypoxic Gas Mixture (10 Per Cent Oxygen + 90 Per Cent Nitrous Oxide).

\begin{tabular}{lccccc}
\hline & & & & & \\
Minutes & 0 & 30 & 60 & 90 & $\begin{array}{c}\text { Saline in } \\
\text { Urine out }\end{array}$ \\
\cline { 5 - 6 } Methoxyflurane & 142 & 132 & 118 & 109 & 99 \\
& 176 & 168 & 163 & 156 & 47 \\
Chloroform & 146 & 152 & 146 & 138 & 133 \\
& 161 & 170 & 163 & 175 & 44 \\
Trichlorethylene & 135 & 143 & 142 & 136 & 137 \\
& 151 & 160 & 164 & 155 & 105 \\
Halothane & 141 & 141 & 146 & 102 & 163 \\
Halothane-Ether & 175 & 154 & 121 & 148 & 49 \\
Azeotrope & 128 & 123 & 106 & 94 & 102 \\
Isoflurane & 137 & 144 & 141 & 144 & 53 \\
& 145 & 148 & 135 & 134 & 167 \\
Enflurane & 138 & 133 & 132 & 104 & 158 \\
& 178 & 159 & 155 & 136 & 109 \\
Diethyl Ether & 129 & 143 & 147 & 130 & 154 \\
& 124 & 175 & 177 & 173 & 40 \\
Fluroxene & 135 & 151 & 144 & 147 & 175 \\
& 130 & 169 & 181 & 170 & 134 \\
Innovar & 133 & 112 & 103 & 113 & 258 \\
& 126 & 116 & 136 & 151 & 70 \\
Thiopentone & 137 & 162 & 171 & 163 & 317 \\
& 174 & 187 & 165 & 188 & 125 \\
\hline
\end{tabular}


TABLE III

Summary of Changes in Minute Volume of Respiration (Litres) and Rate of

Respiration (Per Minute) During Administration of General Anaesthetics With a Hypoxic Gas Mixture (10 Per Cent Oxygen + 90 Per Cent Nitrous Oxide)

\begin{tabular}{|c|c|c|c|c|c|c|c|c|c|c|}
\hline Minutes & 0 & 10 & 20 & 30 & 40 & 50 & 60 & 70 & 80 & 90 \\
\hline Methoxyflurane & $\begin{array}{r}5.3 \\
11\end{array}$ & $\begin{array}{r}5.9 \\
14\end{array}$ & $\begin{array}{r}6.5 \\
14\end{array}$ & $\begin{array}{r}5.4 \\
17\end{array}$ & $\begin{array}{r}6.2 \\
17\end{array}$ & $\begin{array}{r}5.9 \\
18\end{array}$ & $\begin{array}{r}5.7 \\
18\end{array}$ & $\begin{array}{r}6.0 \\
18\end{array}$ & $\begin{array}{r}5.7 \\
18\end{array}$ & $\begin{array}{r}5.3 \\
17\end{array}$ \\
\hline Chloroform & $\begin{array}{r}3.6 \\
18\end{array}$ & $\begin{array}{r}4.5 \\
17\end{array}$ & $\begin{array}{r}4.0 \\
18\end{array}$ & $\begin{array}{r}3.4 \\
18\end{array}$ & $\begin{array}{r}3.9 \\
21\end{array}$ & $\begin{array}{r}4.9 \\
25\end{array}$ & $\begin{array}{r}5.0 \\
27\end{array}$ & $\begin{array}{r}4.3 \\
22\end{array}$ & $\begin{array}{r}4.3 \\
24\end{array}$ & $\begin{array}{r}4.0 \\
25\end{array}$ \\
\hline Trichlorethylene & $\begin{array}{r}4.9 \\
13\end{array}$ & $\begin{array}{r}6.0 \\
17\end{array}$ & $\begin{array}{r}6.1 \\
21\end{array}$ & $\begin{array}{r}6.1 \\
29\end{array}$ & $\begin{array}{c}6.2 \\
29\end{array}$ & $\begin{array}{r}6.0 \\
29\end{array}$ & $\begin{array}{r}6.1 \\
32\end{array}$ & $\begin{array}{r}7.3 \\
35\end{array}$ & $\begin{array}{r}6.6 \\
37\end{array}$ & $\begin{array}{r}6.5 \\
38\end{array}$ \\
\hline Halothane & $\begin{array}{r}6.9 \\
14\end{array}$ & $\begin{array}{r}5.8 \\
24\end{array}$ & $\begin{array}{r}6.1 \\
29\end{array}$ & $\begin{array}{r}7.7 \\
33\end{array}$ & $\begin{array}{r}9.9 \\
33\end{array}$ & $\begin{array}{r}9.0 \\
38\end{array}$ & $\begin{array}{r}7.8 \\
22\end{array}$ & $\begin{array}{r}5.7 \\
24\end{array}$ & $\begin{array}{r}6.1 \\
22\end{array}$ & $\begin{array}{r}5.1 \\
28\end{array}$ \\
\hline $\begin{array}{l}\text { Halothane-Ether } \\
\text { Azeotrope }\end{array}$ & $\begin{array}{r}3.4 \\
9\end{array}$ & $\begin{array}{r}6.0 \\
14\end{array}$ & $\begin{array}{r}4.9 \\
16\end{array}$ & $\begin{array}{r}5.1 \\
15\end{array}$ & $\begin{array}{r}5.5 \\
16\end{array}$ & $\begin{array}{r}5.6 \\
16\end{array}$ & $\begin{array}{r}4.9 \\
16\end{array}$ & $\begin{array}{r}5.1 \\
18\end{array}$ & $\begin{array}{r}5.2 \\
18\end{array}$ & $\begin{array}{r}6.3 \\
22\end{array}$ \\
\hline Isoflurane & $\begin{array}{r}4.4 \\
19\end{array}$ & $\begin{array}{r}2.6 \\
10\end{array}$ & $\begin{array}{r}2.8 \\
9\end{array}$ & $\begin{array}{r}4.1 \\
19\end{array}$ & $\begin{array}{r}4.5 \\
22\end{array}$ & $\begin{array}{r}4.9 \\
17\end{array}$ & $\begin{array}{r}5.2 \\
18\end{array}$ & $\begin{array}{r}4.1 \\
14\end{array}$ & $\begin{array}{r}4.2 \\
17\end{array}$ & $\begin{array}{r}4.0 \\
17\end{array}$ \\
\hline Enflurane & $\begin{array}{r}4.6 \\
14\end{array}$ & $\begin{array}{r}3.1 \\
9\end{array}$ & $\begin{array}{r}3.2 \\
9\end{array}$ & $\begin{array}{r}3.9 \\
14\end{array}$ & $\begin{array}{r}4.4 \\
15\end{array}$ & $\begin{array}{r}5.3 \\
17\end{array}$ & $\begin{array}{r}3.8 \\
13\end{array}$ & $\begin{array}{r}3.3 \\
10\end{array}$ & $\begin{array}{r}3.4 \\
10\end{array}$ & $\begin{array}{r}3.2 \\
10\end{array}$ \\
\hline Diethyl Ether & $\begin{array}{r}2.9 \\
16\end{array}$ & $\begin{array}{r}4.7 \\
13\end{array}$ & $\begin{array}{r}3.9 \\
17\end{array}$ & $\begin{array}{r}5.2 \\
23\end{array}$ & $\begin{array}{r}6.2 \\
29\end{array}$ & $\begin{array}{r}6.6 \\
31\end{array}$ & $\begin{array}{r}7.1 \\
31\end{array}$ & $\begin{array}{r}7.9 \\
35\end{array}$ & $\begin{array}{r}9.3 \\
36\end{array}$ & $\begin{array}{r}9.4 \\
39\end{array}$ \\
\hline Fluroxene & $\begin{array}{r}5.1 \\
15\end{array}$ & $\begin{array}{r}4.6 \\
17\end{array}$ & $\begin{array}{r}4.7 \\
17\end{array}$ & $\begin{array}{r}7.4 \\
27\end{array}$ & $\begin{array}{r}10.8 \\
33\end{array}$ & $\begin{array}{r}10.3 \\
35\end{array}$ & $\begin{array}{r}12.3 \\
43\end{array}$ & $\begin{array}{r}12.1 \\
44\end{array}$ & $\begin{array}{r}10.9 \\
39\end{array}$ & $\begin{array}{r}10.8 \\
40\end{array}$ \\
\hline Innovar & $\begin{array}{r}3.6 \\
11\end{array}$ & $\begin{array}{r}3.8 \\
10\end{array}$ & $\begin{array}{r}5.3 \\
8\end{array}$ & $\begin{array}{r}4.9 \\
10\end{array}$ & $\begin{array}{r}4.7 \\
11\end{array}$ & $\begin{array}{r}4.8 \\
12\end{array}$ & $\begin{array}{r}5.2 \\
12\end{array}$ & $\begin{array}{r}6.1 \\
15\end{array}$ & $\begin{array}{r}7.3 \\
21\end{array}$ & $\begin{array}{r}7.6 \\
23\end{array}$ \\
\hline Thiopentone & $\begin{array}{r}5,1 \\
13\end{array}$ & $\begin{array}{r}5.9 \\
17\end{array}$ & $\begin{array}{r}4.9 \\
20\end{array}$ & $\begin{array}{r}4.8 \\
21\end{array}$ & $\begin{array}{r}5.9 \\
21\end{array}$ & $\begin{array}{c}5.2 \\
18\end{array}$ & $\begin{array}{r}5.4 \\
18\end{array}$ & $\begin{array}{r}5.5 \\
17\end{array}$ & $\begin{array}{r}5.6 \\
20\end{array}$ & $\begin{array}{r}7.4 \\
25\end{array}$ \\
\hline
\end{tabular}

Pulse rate was reduced with methoxyflurane, halothane, isoflurane and enflurane, but rose with chloroform, halothane-ether azeotrope, diethyl ether, fluroxene, Innovar and thiopentone, while no change occurred with trichlorethylene.

No persistent arrhythmias were seen, although occasional premature ventricular contractions occurred with several of the anaesthetics. ST depression appeared in the ECG during the latter part of the anaesthetic periods in some tests with trichlorethylene. Arrhythmias were not observed with chloroform, diethyl ether, enflurane, isoflurane and thiopentone.

Urine output was depressed but did not fall below $30 \mathrm{ml}$ in the 90 -minute period of anaesthesia. Almost all the animals excreted a volume of urine that varied from approximately 25 per cent (diethyl ether) to 75 per cent (trichlorethylene) or more of the saline volume administered during the test; with most of the agents it was approximately 30 per cent (Table II).

\section{Pulmonary Ventilation (Table III)}

There was no over-all change in minute ventilation with methoxyflurane, but the rate of respiration rose about 50 per cent. Halothane, isoflurane and enflurane reduced minute volume; tachypnoea accompanied the change with halothane, whereas the rate was reduced with isoflurane and enflurane. The remaining agents - chloroform, trichlorethylene, halothane-ether azeotrope, diethyl ether, 

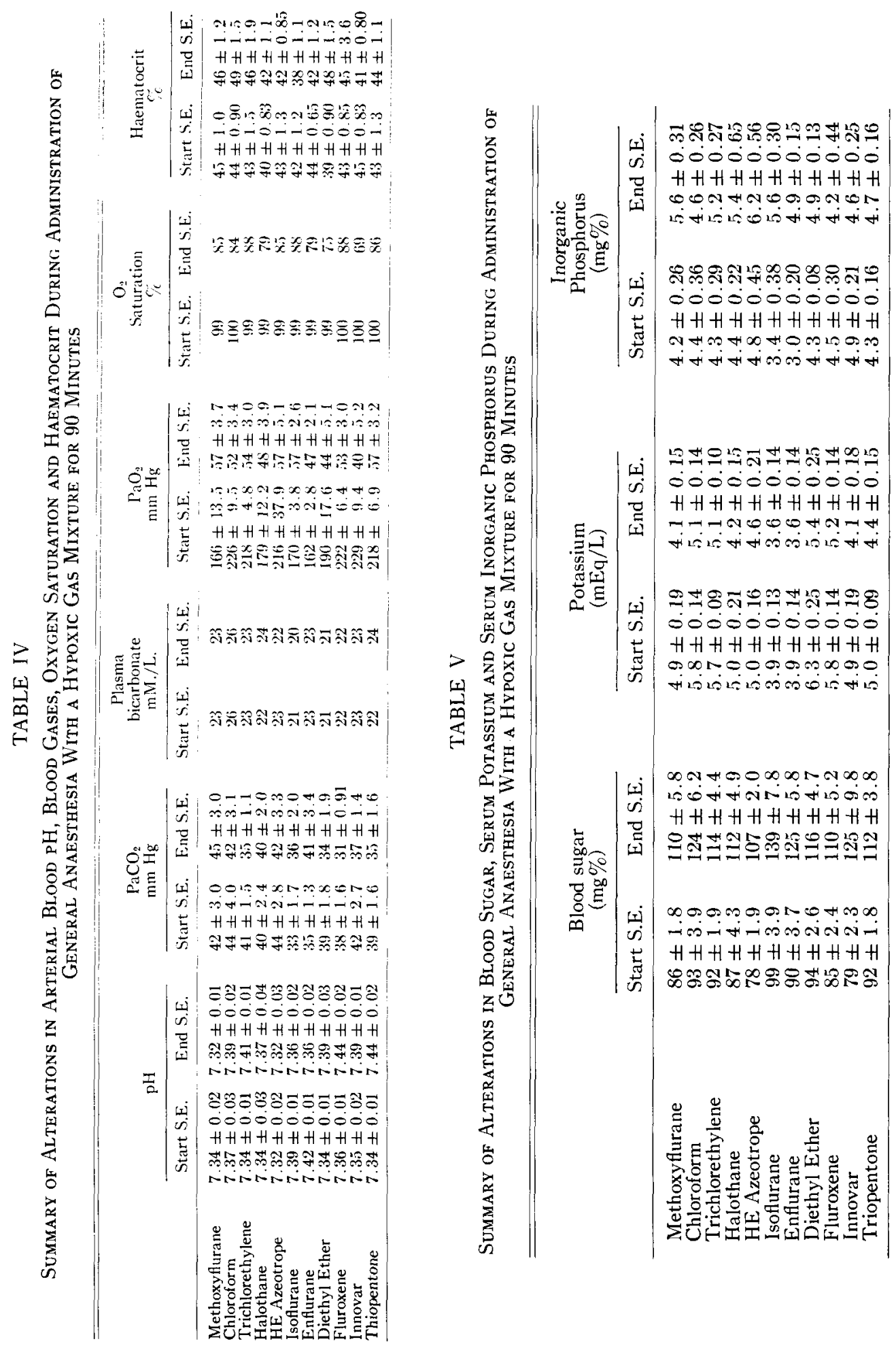
fluroxene, Innovar and thiopentone - raised the minute volume and rate of respiration.

All the dogs had signs of inadequate oxygenation, consistently evident by blueness of the tongue and gums, even though the ventilation was shown to be adequate by the $\mathrm{PaCO}_{2}$ figures (Table IV).

\section{Blood Gases and Haematocrit (Table IV)}

No significant change occurred in the arterial blood $\mathrm{pH}, \mathrm{PaCO}_{2}$ or plasma bicarbonate. The $\mathrm{PaO}_{2}$ invariably fell from over 150 torr to the 40 - to 60 -torr range and oxygen saturation was usually reduced from 100 per cent to less than 85 per cent. Haematocrit tended to rise except with halothane, isoflurane, enflurane and Innovar.

\section{Blood Sugar, Serum Potassium and Serum Inorganic Phosphorus (Table V)}

The hypoxia imposed during anaesthesia was accompanied by hyperglycaemia and hypokalaemia in every test. Inorganic phosphorus usually rose, except with fluroxene and Innovar.

\section{Lactate, Pyruvate, L/P Ratio and Excess Lactate (Table VI)}

Whole blood lactic acid and pyruvic acid rose during all the anaesthetic tests. The only agents that caused an appreciable increase in the $\mathrm{L} / \mathrm{P}$ ratio and excess lactate were diethyl ether and fluroxene.

\section{Biogenic Amines (Table VII)}

Hypoxaemia did not appear to cause any appreciable alteration in the blood histamine and serotonin. Blood insulin increased during isoflurane and enflurane anaesthesia.

Both agents reduced the catecholamines. Data are not shown for the other agents because catecholamine readings were "zero" in several instances, which caused us to question their validity. ${ }^{7}$

Four of the six animals tested with enflurane twitched or had "paddling" movements of the legs, usually intermittently, during this anaesthetic. None of the other tests were accompanied by such behaviour.

All the dogs survived the series of tests without sequelae.

A summary of alterations in the biochemical tests during the experiments is shown in Table VIII. The outstanding changes caused by the reduction of oxygen tension are a consistent rise in blood sugar, a slight fall in serum potassium, elevated lactic acid and pyruvic acid and slight to moderate accumulation of excess lactate. Other biochemical changes are small and inconsistent.

\section{Discussion}

When acute hypoxia due to the inhalation of an atmosphere deficient in oxygen reaches the critical range of approximately 10 per cent of inspired oxygen, it produces a clinical syndrome that is well known and has been described in some detail during the past century. There is cyanosis ${ }^{8}$ and an increased rate and 


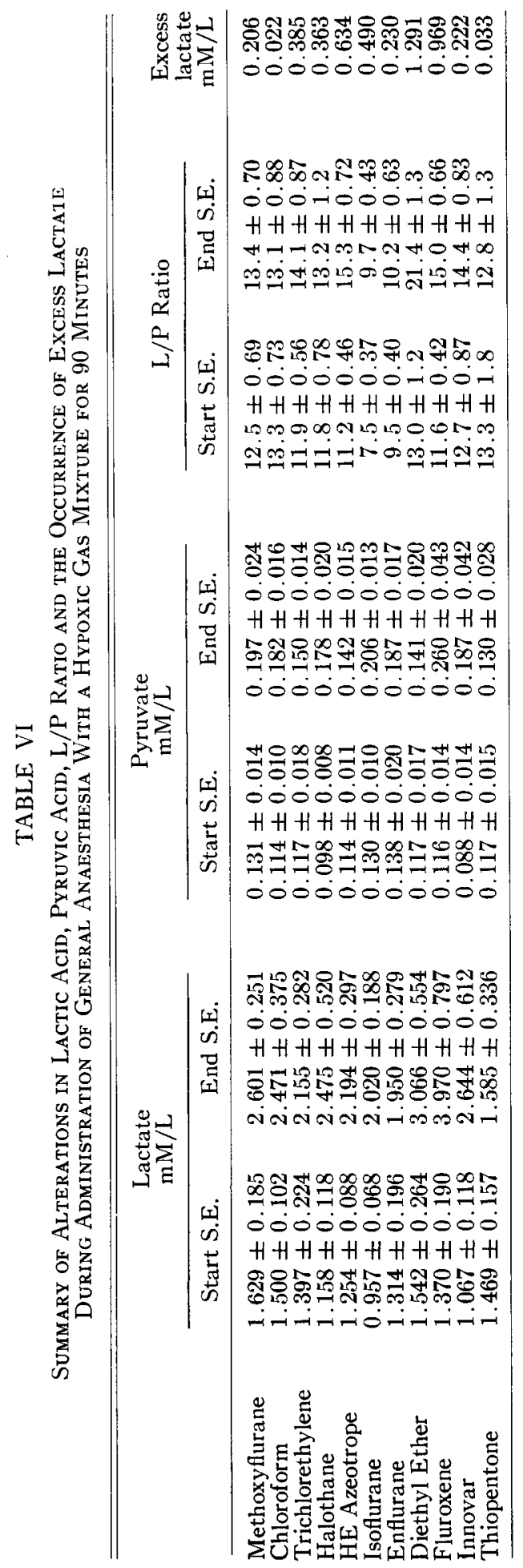


TABLE VII

Summary of Alterations in Biogenic Amines During administration of General AnaEsthesia With Enflurane and Isoflurane With a Hypoxic Gas Mixture for 90 Minutes

\begin{tabular}{lccccc}
\hline & & \multicolumn{2}{c}{ Enflurane } & \multicolumn{2}{c}{ Isoflurane } \\
& & Start \pm S.E. & End \pm S.E. & Start. \pm S.E. & End \pm S.E. \\
\cline { 2 - 6 } Histamine & $\mu \mathrm{g} / \mathrm{L}$ & $19 \pm 2$ & $24 \pm 1$ & $20 \pm 1$ & $19 \pm 2$ \\
Serotonin & $\mu \mathrm{g} / \mathrm{L}$ & $1785 \pm 95$ & $1860 \pm 119$ & $\mathbf{1 6 4 4} \pm 82$ & $1826 \pm 86$ \\
Insulin & $\mu \mathrm{U} / \mathrm{L}$ & $11 \pm 2$ & $16 \pm 4$ & $9 \pm 3$ & $10 \pm 3$ \\
Epinephrine & $\mu \mathrm{g} / \mathrm{L}$ & $0.70 \pm .38$ & $0.50 \pm .34$ & $0.60 \pm .53$ & $0.20 \pm .15$ \\
Norepinephrine & $\mu \mathrm{g} / \mathrm{L}$ & $0.90 \pm .40$ & $0.70 \pm .40$ & $0.50 \pm .33$ & $0.30 \pm .09$ \\
\hline
\end{tabular}

depth of breathing, ${ }^{9-11}$ as well as peripheral vasoconstriction, cold extremities, tachycardia, hypertension, increased cardiac output and electrocardiographic evidence of abnormal conduction such as ST-and T-wave depression in lead II. ${ }^{12,13}$ The effects on the central nervous system include confusion, poor judgment, psychic aberrations, ${ }^{14-16}$ abnormal flicker fusion test response, and encephalographic rhythmic changes such as high-voltage slow waves followed by complete suppression. ${ }^{17}$ These can progress to loss of consciousness. There may also be metabolic changes such as hyperglycaemia, ${ }^{18}$ a rise in serum inorganic phosphorus, an elevated plasma cortisol and an excess of lactate. ${ }^{19}$

Numerous investigations have attempted to explain the physiological basis for these responses to hypoxia with variable success. Most of these studies involved simulated or actual high altitude conditions. Although this subject is of interest to the anaesthetist, the effect of hypoxia in the presence of various anaesthetics has not been thoroughly studied prospectively. Some of the effects of hypoxia were analysed in the well-known "Beecher \& Todd Anesthesia Death Study."20

At surgical depths of anaesthesia, with ample oxygen, both enflurane and isoflurane are known to produce changes in the electroencephalogram, though usually without any accompanying clinical manifestations such as convulsions. Both agents also cause a marked rise in blood sugar as is seen during severe hypoxaemia, and under certain conditions deep enflurane anaesthesia will cause localized muscle twitching, especially in animals, similar to that seen with cerebral hypoxia. Therefore, these two anaesthetic agents were compared with other commonly used inhalational anaesthetics to determine whether the effects observed are indeed unique, and also to determine whether the administration of parenteral or inhalational anaesthetics modifies the response that hypoxia usually evokes in the absence of anaesthesia.

Differences were indeed observed in several instances, as follows: mean arterial blood pressure was appreciably reduced with some of the anaesthetics, including enflurane and isoflurane, instead of rising as is usually seen during hypoxia alone. However, the reduction was much less than expected for the depth of anaesthesia used. Evidently, the reflex hypertension, or alpha-receptor stimulating catecholamine-like effect of hypoxia ${ }^{10,21}$ is at least partially blocked with some anaesthetics and the vasomotor depressant effect is dominant with most of the agents tested, except diethyl ether, fluroxene and thiopentone.

The heart rate was reduced with enflurane, isoflurane, methoxyflurane and 


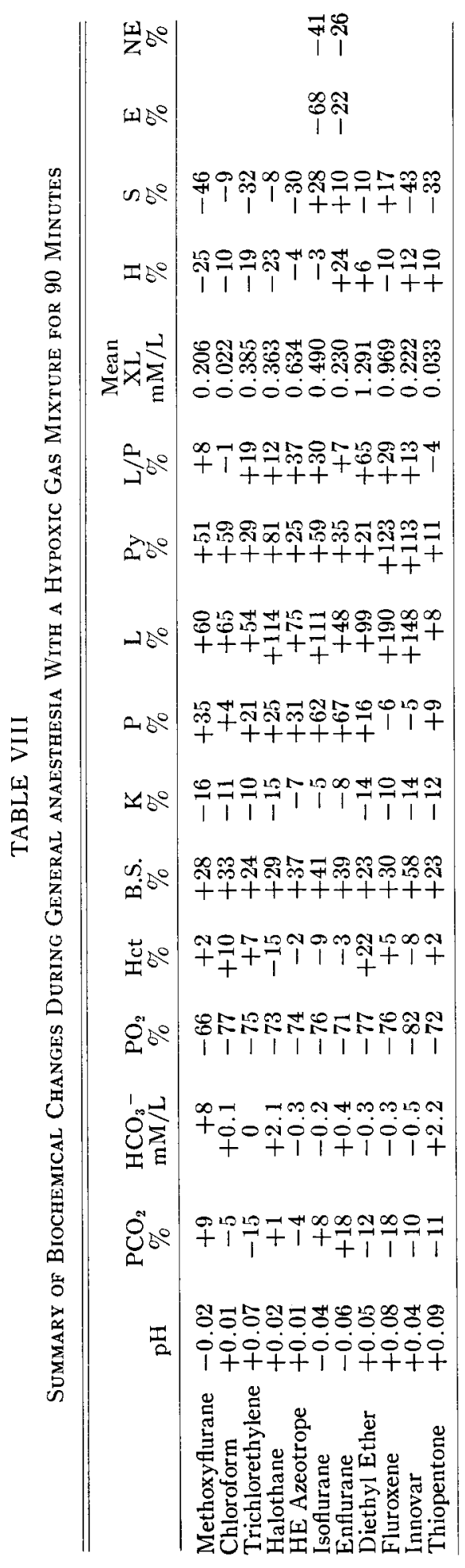


halothane, even though tachycardia is usually seen with marked degrees of hypoxia. The tachycardia is believed to be due to reflex stimulation of the heart from the lungs through vagal nerve fibres. ${ }^{12}$ However, it is apparent that either a stronger direct vagotonic effect or a sympatholytic effect of these anaesthetic agents on the heart overrides the response to hypoxaemia. Trichlorethylene and chloroform did not alter the heart rate appreciably, while the remaining anaesthetics caused tachycardia. Evidently, the six anaesthetics noted above have a persistent dominant vagotonic effect on the cardiac pacemaker.

\section{Electrocardiogram}

Light or deep general anaesthesia sometimes causes auricular arrhythmias. When the hilum of the lung is surgically stimulated, or traction is applied to abdominal or pelvic viscera, ventricular arrhythmias often occur. These may be aggravated by hypercarbia and/or hypoxia. During our tests, the electrocardiogram was remarkably stable, even with trichlorethylene and halothane, which commonly cause a shift in the pacemaker and, occasionally, ventricular arrhythmias during deep anaesthesia. This result may have been due to the reflex increase in pulmonary ventilation initiated by the hypoxic gas mixture acting on the peripheral chemoreceptors. This probably kept the oxygen tension in the heart above the level at which cardiac arrhythmias and other ECG abnormalities may occur. A moderate degree of hypoxaemia may also depress the irritability of the myocardium provoked by such agents as chloroform, trichlorethylene and halothane, but such a response seems unlikely.

\section{Urine Output}

Oliguria is almost invariably seen during general anaesthesia regardless of the agent employed. One would therefore expect hypoxaemia to aggravate this response, since reduced oxygen content in the blood may promote shunting of the circulation away from the glomeruli and so further reduce renal filtration. However, the urine output was of a magnitude similar to that seen in other anaesthetic tests without hypoxaemia or with milder degrees of hypoxaemia. ${ }^{1,2,22-25}$

\section{Pulmonary Ventilation}

Evidently the depression of respiration usually caused by general anaesthesia was almost uniformly counterbalanced in our anaesthetic tests by the chemoreceptor stimulation caused by the low oxygen tension. Halothane, enflurane and isoflurane were the most potent respiratory depressants, since the hypoxaemia did not restore breathing quite as well as with the other agents. The tachypnoea usually seen during deep anaesthesia with trichlorethylene, halothane, diethyl ether and fluroxene occurred in most of the hypoxic tests. The only agents that did not accelerate the breathing rate were enflurane and isoflurane.

In all of the tests, the animals had cyanosis of the tongue, gums and skin, indicating that there was at least a moderate degree of unsaturation of the haemoglobin ( $>5$ grams $/ 100 \mathrm{ml}$ ). 


\section{Blood Gases and $p H$}

It was surprising to find that the arterial blood $\mathrm{pH}$ and $\mathrm{PCO}_{2}$ were hardly changed with most of the anaesthetics and both of these blood parameters were within the normal range. These observations support the conclusion that the reflex respiratory stimulation caused by the hypoxaemia in most instances overcomes the usual tendency to hypoventilation due to the general anaesthetic. Further evidence of the respiratory stimulation due to hypoxaemia was indicated by the blood gas analyses. The $\mathrm{PaO}_{2}$ and $\mathrm{SaO}_{2}$ were, in most instances, appreciably higher than the 35- to 40-torr and 70 per cent saturation respectively, expected when only approximately 10 per cent oxygen is present in the inspired atmosphere.

Early studies of hypoxaemia indicated that acidosis occurred. Further investigation revealed not an accumulation of abnormal amounts of acids such as lactic acid, but rather reduced excretion of ammonia. It was postulated that there was probably a reduced formation of ammonia in the body. Subsequently, Haldane's group showed that hypoxaemia caused an alkaline urine to form, due to reduced excretion of acid and ammonia, and dubbed this the "alkalosis theory" which they felt was due to hyperventilation, reduced $\mathrm{PaCO}_{2}$ and elevated arterial $\mathrm{pH}^{2 \mathrm{~g}}$ The general opinion now is that severe hypoxaemia produces mainly an acidotic disturbance with accumulation of not only lactic acid but probably acetoacetic and betahydroxybutyric acid and acid metabolites arising from muscular contractions. This acidosis is initially masked by the hyperventilation and reduction of $\mathrm{PaCO}_{2}$, but, as the hypoxia persists the metabolic acidosis becomes obvious. ${ }^{27,28}$

\section{Haematocrit}

Hypoxaemia does not ordinarily cause contraction of the dog's spleen and ejection of red blood cells into the general circulation until the $\mathrm{PaO}_{2}$ falls to about 6 torr. ${ }^{29}$ However, several of the general anaesthetics, especially diethyl ether, appear to cause an early rise in the haematocrit. The latter agent is well known to cause splenic contraction. The reason for the response is not clear, although catecholamine release is a reasonable explanation. None of the other anaesthetics appear to cause a similar degree of splenic contraction, as indicated by the far smaller rise in the haematocrit. In a few anaesthetic tests, notably with enflurane and isoflurane, the haematocrit tended to fall. Evidently, hypoxaemia combined with general anaesthesia does not obviously influence the splenic response seen with anaesthesia alone. ${ }^{1}$

\section{Blood Sugar}

Hypoxia usually mobilises liver glycogen, resulting in an elevated blood glucose and glycosuria. Whether or not this response is initiated by release of catecholamines has not been clearly demonstrated either in unanaesthetized or in anaesthetized man or animals. ${ }^{1,2,18,22-25}$ It is undoubtedly a vital response to stress of hypoxaemia ensuring an adequate supply of glucose to the brain and heart, and was seen uniformly in this study with all the anaesthetics, including those that ordinarily do not appear to elevate blood sugar. Clinical and laboratory observations indicate that an elevated blood glucose can substantially satisfy the energy requirements of the well-perfused hypoxic heart by anaerobic conversion to lactate and this principle has been used in the prevention and treatment of 
heart failure. ${ }^{30-32}$ The elevated blood sugar during anaesthesia and hypoxia may therefore be considered an added protective mechanism for the myocardium during periods of oxygen restriction, similar to its action in dogs in whom cardiac necrosis is prevented by glucose after experimental coronary artery ligation. ${ }^{33}$ Elevated circulating blood glucose also raises the serum osmolarity, which stimulates left ventricular function and may decrease potassium loss from ischaemic muscle. $^{34,35}$

\section{Serum Potassium}

Although asphyxia stimulates the adrenal glands to secrete catecholamines, thus causing the liver to mobilize potassium, ${ }^{36}$ there appears to be no such effect with heart failure or with hypoxaemia. All investigations indicate clearly that serum potassium is reduced during myocardial hypoxaemia with or without anaesthesia. ${ }^{37}$ In the case of anaesthesia, the reduction occurs even without hypoxaemia and appears to be most evident in the presence of moderate hyperventilation (hypocarbia).1,2,7,22-25 The response is the same with enflurane and isoflurane. No clear explanation for this change has appeared, although it has been attributed to impaired insulin metabolism. ${ }^{38}$

\section{Serum Inorganic Phosphorus}

A significant rise in serum inorganic phosphorus is usually seen during the use of all the inhalation and parenteral anaesthetics tested. ${ }^{1}$ The opposite is seen both during graded haemorrhage and when a hypoxic gas mixture is delivered using controlled respiration. ${ }^{3,23}$ The reason for these alterations has not been explained, although it may be part of the mechanism which regulates liver glycolysis by influencing the activity of the enzyme phosphofructokinase..$^{39}$

\section{Lactate and Pyruvate}

Hypoxaemia caused a slight to moderate rise in lactic and pyruvic acids with all the anaesthetics, but only diethyl ether and fluroxene anaesthesia were associated with an appreciable rise in the $\mathrm{L} / \mathrm{P}$ ratio and excess lactate production. This observation was similar to that reported with lesser degrees of hypoxia. ${ }^{1,2,19}$

\section{Biogenic Amines}

None of the anaesthetics were associated with a gross change in the blood level of histamine, serotonin or insulin. As in previous studies, the observed changes in the blood levels of epinephrine and norepinephrine were probably too small to be clinically significant. ${ }^{7}$ During hypoxia, both enflurane and isoflurane tended to reduce blood epinephrine and norepinephrine. This was similar to observations with halothane and the halothane-ether azeotrope, while the remaining anaesthetics tended to raise the catecholamines to some degree, as was seen with hypoxia and controlled respiration. ${ }^{2}$

\section{Summary AND Conclusions}

Crossover studies were done on 22 large, trained, male mongrel dogs using 11 general anaesthetics that were given at least six times each with a hypoxic mixture of nitrous oxide and oxygen. Respiration was spontaneous and the anaesthetic 
concentrations were increased to a peak inhaled value over the initial 30 minutes, then held steady for a further 60 minutes. Biochemical laboratory tests were done before and at the end of each anaesthetic and vital signs were monitored throughout.

Hypoxia during general anaesthesia was associated with alterations in vital signs similar to those which are frequently associated with hypoxia without anaesthesia, such as cyanosis, respiratory stimulation and cardiovascular stimulation. Most anaesthetics, however, modified the reflex stimulation caused by hypoxia. For example, the heart rate did not rise during hypoxia with methoxyflurane, halothane, enflurane, isoflurane, trichlorethylene and chloroform anaesthesia, probably due to suppression of a cardiopulmonary vagal reflex. On the other hand, the rise in blood pressure usually produced by hypoxia was not suppressed by diethyl ether, fluroxene or thiopentone, while the other agents did modify this reflex. General anaesthesia appeared to suppress cardiac rhythmic disturbances caused by hypoxia, possibly by reducing myocardial irritability.

Adding hypoxia to general anaesthesia did not appreciably reduce urine output below that usually seen with anaesthesia alone.

Hypoxia appeared to stimulate pulmonary ventilation even during deep general anaesthesia, indicating that chemoreceptor responsiveness to reduced oxygen tension is not noticeably depressed. This response was reflected in the blood gas analyses that showed near normal arterial $\mathrm{pH}$ and $\mathrm{PaCO}_{2}$ and only moderately reduced $\mathrm{PaO}_{2}$ and $\mathrm{SaO}_{2}$, while the haematocrit tended to rise as expected.

The blood sugar rose in all instances, probably as a protective reflex to maintain the myocardial energy supply. Serum potassium was reduced in response to general anaesthesia, perhaps because of impaired insulin metabolism. The serum inorganic phosphorus tended to rise, possibly in response to the need for mobilizing liver glycogen. Lactate and pyruvate rose in response to the hypoxaemia, as expected, due to an effect on the Krebs cycle, but only diethyl ether and fluroxene caused appreciable excess lactate. As observed previously, measurements of the biogenic amines only showed minor variations, probably because the methods of measurement have not been developed sufficiently to show up small variations.

It appeared from this study that, in the absence of surgical trauma, quite a marked degree of hypoxia (low inspired oxygen tension) is tolerable for up to 90 minutes, with a moderately deep level of anaesthesia maintained for approximately one hour. Both of the recently developed inhalation anaesthetics, enflurane and isoflurane, behave under these conditions in a manner not unlike halothane, methoxyflurane, trichlorethylene or chloroform.

\section{RÉSUMÉ}

Des études croisées furent effectuées sur 22 chiens mongrel entraînés et bien constitués avec 11 agents anesthésiques généraux qui furent administrés au moins 6 fois à chacun avec un mélange hypoxique de protoxyde d'azote et d'oxygène. Sous respiration spontanée, les concentrations anesthésiques furent augmentées jusqu’à un certain maximum au cours d'une période initiale de 30 minutes, et par la suite maintenues à ce niveau pour une période subséquente de 60 minutes. 
Des analyses biochimiques furent effectuées avant et à la fin de chaque anesthésie, tandis que les signes vitaux étaient surveillés tout au cours de l'expérience.

L'hypoxie en cours d'anesthésie générale fut associée à des modifications des signes vitaux comparables à celles qui sont fréquemment rencontrées lors d'hypoxie sans anesthésie telles que cyanose, et stimulation des systèmes respiratoire et cardio-vasculaire. La plupart des agents anesthésiques modifient cependant le réflexe de stimulation provoqué par l'hypoxie. Par exemple, le rythme cardiaque n'augmente pas en période d'hypoxie au cours d'anesthésie au méthoxyflurane et chloroforme probablement par suppression d'un réflexe vagal cardio pulmonaire. Par ailleurs, l'augmentation de pression sanguine habituellement engendrée par l'hypoxie fut également observée lors d'anesthésie au diéthyl éther, fluoroxène ou thiopentone, tandis que les autres agents entraînaient des modifications de ce réflexe. L'anesthésie générale fait disparaître les troubles du rythme cardiaque causés par l'hypoxie, possiblement par diminution de l'irritabilité myocardique.

L’hypoxie associée à l’anesthésie générale n’entraine pas de réduction appréciable dans le débit urinaire comparativement à celle qui est notée au cours de l'anesthésie seule.

L'hypoxie apparaît comme un stimulant de la ventilation pulmonaire même sous anesthésie générale profonde indiquant que la réponse des chemorécepteurs à une tension réduite en oxygène n'est pas déprimé de façon appréciable par l'anesthésie. Cette réponse fut confirmée par l'analyse des gaz sanguins qui montraient un $\mathrm{pH}$ et une $\mathrm{PaCo}_{2}$ pratiquement normal avec une réduction modérée de la $\mathrm{PaO}_{2}$ et de la $\mathrm{SaO}_{2}$ tandis que l'hématocrite tendait à s'élever tel que prévu.

La glycémie s'éleva dans tous les cas, probablement comme réflexe protecteur pour maintenir suffisante la source d'énergie myocardique. Le potassium sérique s'abaissa en réponse à l'anesthésie générale possiblement par suite d'une perturbation dans le métabolisme de l'insuline. Le phosphore inorganique eut tendance à s'élever possiblement en réponse à la mobilisation du glycogène hépatique. Le lactate et le pyruvate s'élevèrent, tel que prévu, en réponse à l'hypoxémie par perturbation du cycle de Krebs, mais le diéthyl éther et le fluoroxène furent les seuls agents qui causèrent un excès de lactate appréciable. Tel qu'observé antérieurement, le dosage des amines biogènes ne montra que des modifications mineures, probablement parce que les méthodes de dosage ne sont pas encore suffisamment précises pour mettre en évidence de petites variations.

Il se dégage de cette étude que, en l'absence de traumatisme chirurgical, un degré d'hypoxie assez marquée ( $\mathrm{FiO}_{2}$ basse) est relativement bien toléré pour une période allant jusqu'à 90 minutes avec un degré modérément profond d'anesthésie maintenu pour approximativement une heure. Deux des nouveaux agents anesthésiques par inhalation, l'influrane et l'isoflurane reproduisant, dans ces conditions, les effets de l'halothane, du méthoxyflurane, du trichloréthylène et du chloroforme.

\section{ACKNOWLEDGMENTS}

The authors are grateful to Benjamin F. Africa, M.D., Christina Bisset, R.N., Robert Gelder, B.Sc., R.T., and George Mann, R.T., for technical assistance. 


\section{REFERENCES}

1. Dobkin, A.B., Byles, P.H., \& Neville, J.F., JR. Neuroendocrine and metabolic effects of general anaesthesia during spontaneous breathing, controlled breathing, mild hypoxia and mild hypercarbia. Can. Anaesth. Soc. J. 13: 130 (1966).

2. Dobkin, A.B., Byles, P.H., Africa, B.F., \& Neville, J.F., Jr. The neuroendocrine and metabolic effects of general anaesthesia associated with acute hypoxia and acute hypercapnia. Can. Anaesth. Soc. J. 14: 442 (1967).

3. Dobkin, A.B. \& Byles, P.H. Laboratory evaluation of $\bar{E}$ thrane, Forane, Halothane, Methoxyflurane and Fluroxene. Unpublished report to Airco (1969).

4. TENNEY, S.M. \& LAMB, T.W. Physiological consequences of hypoventilation and hyperventilation. In Handbook of Physiology, Section III: Respiration, Vol. II, Fenn, W.O. and Rahn, H., editors. Washington, D.C., American Physiological Society (1965).

5. Bendixen, H.H. \& LAver, M.B. Hypoxia in anesthesia: a review. Clin. Pharmacol. Therap. 6: 510 (1965).

6. Neville, J.F., JR. \& GELDER, R.L. Modified enzymatic methods for the determination of L- $(+)$-lactic acid and pyruvic acids in blood. Am. J. Clin. Path. 55: 152 (1971).

7. Dobkin, A.B., Byles, P.H., Arandia, H.Y., Ghanooni, S., Nishioka, K., \& Levy, A.A. Comparative metabolic responses to halogenated anaesthetics. Acta Anaes. Scand. 16: 69 (1972).

8. LundscaArd, C. \& VAn Slyxe, D.D. Cyanosis. Medicine 2: 1 ( 1923).

9. Dripss, R.D. \& Comroe, J.H., JR. The effect of the inhalation of high and low oxygen concentrations on respiration, pulse rate, ballisto-cardiograph and arterial oxygen saturation (oximeter) of normal individuals. Am. J. Physiol. 149: 277 (1947).

10. Heymans, C. \& Neil, E. Reflexogenic areas of the cardiovascular system, lst ed. Boston: Little, Brown \& Co. (1958).

11. Nielsen, M. \& SMrth, H. Studies on the regulation of respiration in acute hypoxia. Acta Physiol. Scand. 24: 293 (1952).

12. Daly, M. DEB. \& ScotT, M.J. The effects of stimulation of the carotid body chemoreceptors on heart rate in the dog. J. Physiol. 144: 148 (1958).

13. Anderson, D.P. et al. Circulatory changes during fainting and coma caused by oxygen lack. J. Physiol. 104: 426 ( 1946).

14. Hexmans, C. Survival and revival of nervous tissue after arrest of circulation. Physiol. Rev. 30: $375(1950)$.

15. Downing, S.E., Mitcheld, J.H., \& Wallace, A.G. Cardiovascular responses to ischemia, hypoxia and hypercapnia of the central nervous system. Am. J. Physiol. 204: 881 (1963).

16. Van Ltere, E.J. \& Stickney, J.C. Hypoxia. Chicago: University of Chicago Press (1963).

17. Meyer, J.S. \& Gaustaut, H., editors. Cerebral Anoxia and the Encephalogram. Charles C. Thomas, Springfield, Illinois (1961).

18. Stickney, J.C., Northup, D.W., \& VAN Liere, E.J. Blood sugar and dextrose tolerance during anoxia in the dog. Am. J. Physiol. 154: 423 (1948).

19. Huckabee, W.E. Relationships of pyruvate and lactate during anerobic metabolism. IH: Effect of breathing low oxygen gases. J. Clin. Invest. 37: 264 (1958).

20. Beecher, H.K. \& Tod, D.P. A study of deaths associated with anesthesia and surgery. Ann. Surg. 140: 2 (1954).

21. Comroe, J.H., Jr., \& Dripps, R.D., Jr. Applied Physiology. Ann. Rev. Physiol. $7: 653$ $(1945)$.

22. Doвkin, A.B. \& Byles, P.H. Comparison of anaesthesia with Innovar, halothane and methoxyflurane-nitrous oxide. Acta Anaesth. Scand., Suppl. XVIII (1966).

23. Dobkin, A.B., Byles, P.H., \& Neville, J.F., Jr. Neuroendocrine and metabolic effects of general anaesthesia and graded haemorrhage. Can. Anaes. Soc. J. 13: 453 (1966).

24. Dobkin, A.B., Heinrich, R.G., Israel, J.S., Levy, A.A., Neville, J.F., Jr., \& Ounkasem, K. Clinical and laboratory evaluation of a new inhalation agent, compound $347\left(\mathrm{CHF}_{2}-\mathrm{O}-\right.$ $\mathrm{CF}_{2}-\mathrm{CHF} \mathrm{Cl}$ ). Anesthesiology 29: 275 ( 1968).

25. Dobkin, A.B., Byles, P.H., Ghanooni, S., \& Valbuena, D.A. Clinical and laboratory evaluation of a new inhalation anaesthetic: Forane (compound 469) $\mathrm{CHF}_{2}-\mathrm{O}-\mathrm{CH} \mathrm{Cl}$ $F_{3}$. Can. Anaes. Soc. J. 18: 264 (1971).

26. Haldane, J.S., Kellas, A.M., \& Kennaway, E.L. Experiments on acclimatization to reduced atmospheric pressure. J. Physiol. 53: 181 (1919-20). 
27. Haggard, H.W. \& Henderson, Y. Hemo-respiratory functions. J. Biol. Chem. 47 : 421 (1921).

28. Henderson, Y. \& Greenberg, L.A. Acidosis: acid intoxication, or acarbia? Am. J. Physiol. 107: 37 (1934).

29. Kramer, K. \& LuFt, U.C. Mobilization of red cells and oxygen from the spleen in severe hypoxia. Am. J. Physiol. 165: 215 (1951).

30. MüLLER, E.R. Über die aerobe und anaerobe Stoffwechselkapazität des isolierten Warmblüterherzens. Pflugers Arch. ges. Physiol. 276: 42 (1962).

31. So̊ni-Parlcares, D., et al. Effects of an intravenous infusion of a potassium-glucoseinsulin solution on the electrocardiographic signs of myocardial infarction. Am. J. Cardiol. 9: 166 ( 1962).

32. Leading Article. Glucose and the heart. Lancet 2: 1295 (1972).

33. Maroko, P.R., et al. Effect of glucose-insulin-potassium on myocardial infarction following experimental coronary artery occlusion. Circulation 45: 1160 (1972).

34. Wildenthal, K., Mierzwiak, D.S., \& Mitchell, J.H. Acute effects of increased serum osmolality on left ventricular performance. Am. J. Physiol. 216: 898 (1969).

35. Burke, W.M., et al. Effects of glucose and nonglucose infusions on myocardial potassium ion transfers and arrhythmias during ischaemia. Am. J. Cardiol. 24: 713 (1969).

36. Ziegler, M.R. Plasma electrolytes as affected by insulin and by varying partial pressures of atmospheric gas. Proc. Soc. Exp. Biol. Med. 43: 165 (1940).

37. Flear, C.T.G. Alterations in water and electrolyte distribution in congestive heart failure and their significance. Ann. N.Y. Acad. Sci. 156: 421 (1969).

38. TAYlon, S.H. Editorial: Insulin and heart failure. Br. Heart J. 33: 329 ( 1971 ).

39. Reacen, D.M. Adjustments of glycolysis to energy utilization in the perfused rat heart: The effect of changes in the ionic composition of the medium in phosphofructokinase activity. J. Biol. Chem. 239: 381 ( 1964 ). 